\title{
The Influence of Political Mobilization Music on the Status of National Cohesion in Nairobi County, Kenya
}

\author{
Ruth M'mbwaya Agesa \\ Crispinous Iteyo \\ Department of Peace and Conflict Studies \\ Masinde Muliro University of Science and Technology \\ Kenya
}

\begin{abstract}
The paper assesses the nexus between political mobilization musicic and National cohesion in Nairobi County, Kenya. The study adopted descriptive research design with mixed method approach, utilizing both primary and secondary data. The study was based on the conceptual framework informed by Music Meaning Theory. The study population consisted of 1015 citizens/ teachers, political mobilization musicians and government officials. The sample size was 156 respondents. Data for the study was collected using questionnaires, FGDs and in-depth interviews with key informants. Data was gleaned and analysed by descriptive and inferential statistics using Statistical Package for Social Science. From the findings, the study established that averagely $75 \%(n=156)$ of all respondents agreed to the facts that; PMM influenced the Status of National Cohesion among Kenyans in Nairobi. PMM brought Peaceful coexistence, Tolerance among each other, Diversity and inclusivity and that trust among communities is still lower because ethnicity is still considered among the people. On whether PMM brought about peaceful coexistence among Kenyans, $54 \%(n=156)$ said yes while $46 \% \quad(n=156)$ said no, 30\% $(n=156)$ agreed to the fact that PMM brought about trust among communities while $70 \%(n=156)$ disputed. On whether PMM influenced tolerance among each Kenyans, 65\% $(n=156)$ said yes $45 \% \quad(n=156)$ said no. 62\% $(n=156)$ of respondents said PMM brought about diversity and inclusivity among communities while $38 \%(n=156)$ disputed.
\end{abstract}

Keywords : Political mobilization music, influencing, national cohesion

\section{Introduction}

The use of music in political situations has been practiced world over in many situations, with varied objectives. There exist songs that largely communicate the need for people to embrace and appreciate their nationhood referred to us patriotic songs. Others focus on political expediency, where they promote political ideologies only. These may be referred to as political songs. Others talk about the nation, like the instance of anthems that promote the philosophy of respective countries, what may be insinuated as National songs. An overriding characteristic in all the songs, however, is that fact that they are a factor of, instigated by, or meant to promote certain political features of a nation, or otherwise, political factors led to their composition and use within a country's system generally refer to as political mobilization songs. This study, therefore, sought to demonstrate how such songs have influenced the status of National cohesion of Kenyan people, with specific reference to Nairobi County, from 1963 (post-colonial Kenya), through the Nyayo era under the rule of Daniel Arap Moi to the current multiparty (Millenium) era. Globally, regionally \& locally PMM had two fold impact on national cohesion by fostering peace or causing conflicts e.g. in America, Nigeria, \& Kenya (Collins \& Ace, 2003)

The study sought to find out the influence of political mobilization music on the status of national cohesion in Nairobi county Kenya. The findings are discussed under three variables in the subsequent sub headings.

\section{Literature Review}

Music gets people thinking, talking, and doing. Elections require a deep knowledge of the contribution and understanding of the important role of politicians. They should deliver the responsibility and accountability of governance to the people. Democracy exists when the relationship between the governed and the government abides by the principle that the state is at the service of the citizens and not the citizens at the service of the state, that the government exists for the people. For a successful transformation of the electioneering campaign, music plays a prominent role in our lives for instance Redemption Song by Bob Marley Ndunde (2016), opines that the knowledge of the African cultural value systems provides the understanding to interpret African songs and deduce full meanings from the communication experience. 
Music has always been the most visible attempt employed by ourselves to listen to ourselves. African music is a powerful medium of communication, through which human actions and reactions are expressed. It provides a forum to mirror the society so that members could understand things better and learn more about life. African music focuses on the teaching of morality, building restraints in to the psyche of the public and in settling conflicts.

In the CD by Oshin of 2019, he asserts that music centres on folklore which crystallizes the history, philosophy, arts and literature of the people. Music is a social organizer. It supervises the operation of established government, assists in the maintenance of the land, safeguards and perpetuates tradition. Furthermore, traditional music discourages the degeneration of personal or corporate morals, promotes social equity and fights injustice, crowns rulers, welcomes births, buries the dead, enforces rule of law and enlivens different purposes of communal get together. It is perhaps not generally recognized how widely political songs are used in Africa.

By the late 1950s and early 1960s political songs in Africa seem to have become a standard accompaniment of recognized political parties and the election campaigns that were by now becoming more and more a feature of political activity in African colonies and ex-colonies. Songs formed part of election campaigns in, for example, Sierra Leone and Senegal in 1957, Nyasaland in 1961, and Northern Rhodesia in 1962. Some politicians managed to exploit oral propaganda even further and, like the Western Nigerian leader Adelabu, organized the circulation of gramophone records of songs supporting them (Lopéz-Vinader, (2008). Altogether there is still great reliance on oral means of propaganda speeches, mass meetings, and songs in keeping with the still largely non-literate or semi-literate mass electorate for whom the written word is of relatively lesser significance.

Northern Rhodesia (later Zambia) seems to have been particularly rich in organized political songs in the vernacular, sometimes specially composed and written for the party, and often sung by official mass choirs. Several have been published among those written for the African National Congress (A.N.C.) in the late 1950s. One, cast in the form of a praise song, honouring Nkumbula, President of the A.N.C., had the familiar purpose of attempting to project a leader's image to the mass of followers: Mr. Nkumbula, we praise you. (Rhodes 1962: 18)

In Uganda, what was featured in "how music has become the new tool of political mobilization ahead of 2016 polls" (The writer is a senior anchor and reporter at NTV Uganda) argued that Politicians recruit musicians to promote and mobilize supporters owing to the fact that people intending to contest for elective positions have found music as a good tool for mobilization. Besides mobilizing supporters, no scientific research has been done to establish exactly how the message in these political songs appeals to people. Lately, this trend has become a contentious issue but it is not new at all. In the 1950s and 60s, when Ugandans started to demonstrate a level of political awareness, politicians did not look at music as a tool that could work to their benefit.But elsewhere, such as South Africa and USA, politicians and activists had long before discovered the power of music. For instance, the song, We Shall Overcome, was used by African American activists to rally for their rights to vote, and assemble, among other rights. However, the 1990s were also hostile to the new breed of Ugandan musicians engrossed in the 'raga' genre. Most people viewed the artistes as bayaaye (loosely translated as society misfits). As musician Moses Ssali, aka Bebe Cool, puts it, the music industry was not booming. "We were looked at as lumpens. Musicians were so laid back." Bebe Cool is an artiste of modern times who has been around NRM circles and specifically party leader President Museveni. When I wake up) by (Bebe Cool) The Uganda People's Congress had formulated mobilization chants which were frequently used even at State functions. Both the youth and party members would chant in unison to the admiration of struggling political parties then. Women dressed in African kitenge fabric on which former president Milton Obote's face was printed, school children in old uniforms and men dressed as they wished all sang about UPC most times praising Obote for his government's achievements.

Veteran singer David Jjingo remembers party members who sang for UPC with passion. "They would sing and dance to their common tune... ooh maama, the congress of the people... They were powerful indeed." By (David Bowie)In the 1980s, Democratic Party would also come up with their Egumire Egumire DP tune that is sang with energy but with little appeal of musicality in it. Music featured much on the political scene of 1980 during the general election and after. Dr Obote and his party claimed victory in the election that was allegedly more of a widely staged show of irregularities. The same election led Uganda to the civil war of 1981 to 1986. Mr Museveni, then of the little known Uganda Patriotic Movement (UPM), fulfilled his threat of launching a guerrilla war to redeem Uganda from injustices. The National Resistance Army (NRA) had officially started. During the war, the NRA used the arts to mobilize citizens to support the cause as well as boost the morale of the fighters. The rebel outfit gave the Obote government the worst challenging times. Hitting the rebel areas with mighty military force did not deter the guerrilla fighters who stood their ground with inferior rifles. One of the things that kept these men advancing in the bush was the cheapest of all music. "We sang morale-boosting songs in different languages. It is those songs that kept the spirit. In the start these songs were in Swahili, Luganda and Ruyankore because most of the first fighters recruited were from the central and western regions," 
The Chief Political Commissar, Col Felix Kulayigye, said. Fighters were not in combat all the time. So, music would be used to occupy them as they got to appreciate the purpose of the struggle through lyrics they sang. When the late Brig Chefe Ali joined NRA, his comrades remember him as a reserved man with a span of knowledge and talent. Brig Chefe had trained in Mozambique before with fighters of the Front for the Liberation of Mozambique. He knew the art of resistance. He had learnt from Mozambique that music fuels the mind of a man in the centre of an important struggle.

He taught NRA fighters morale-boosting songs. When a fighter fell to enemy assault, fighters would sing in memory of them. When they captured new ground, tunes like Moto Wawaka would be sang. Other songs were to mobilize the population. "We started operating a radio frequency in the bush." After the bush war, NRA continued to use music as is when it changed to UPDF. Artistes were doing songs of hope. Uganda had been hit by post-war challenges like disease, hunger and poverty. Bobi Wines' song on condemimg violence.was among the famous tunes then. Tension again engulfed the country in 1996 campaigns and election time. Many Ugandans, feared that what happened in 1980 might resurface.

Two candidates took on Mr Museveni... Kibirige Mayanja and DP's Kawanga Ssemogerere. Mr Museveni comfortably won the race. Voters sang a few slogans in support of candidates but not with much interest and zeal as it would later be, in 2001 and 2006. In 2006, there was a controversial episode in Parliament in which MPs quashed a clause in the Constitution that restricted presidential terms. The excitement and displeasure about the decision was talk across the country. Mr Museveni and NRM's supporters would chant bamwongere ekisanja to mean add him [Museveni] another term. Towards 2006, real songs in support of kisanja [third term] started. Artistes, known, less known and not known at all, offered solicited and unsolicited works in support of Mr Museveni. Notably, The Kads Band and Bebe Cool did a whole album with political songs in support of Museveni. Then a defence minister, Amama Mbabazi launched the album and bought a copy at Shs7 million. "There is a lot of opportunity that musicians have to tap into," says Bebe Cool. Afrigo Band's Moses Matovu links artistes singing mobilization songs this to one thing, money.

“They [artistes] don't sing because they truly love those parties. They are looking for money. Personally, I don't sing politics anymore." By 2003, Bebe Cool was already friends with President Museveni despite his father, Jaberi Bidandi Ssali falling out with Mr. Museveni over the lifting of term limits. In 2005/6, approximately Shs120 million was spent by NRM on artistes for mobilization according to reports then.

The opposition mainly depended on music that was done by artistes who had no intention to use it for campaigning. Ronald Mayinja's 2005 Tuli ku Bunkenke topped the list. "I composed the song because I was seeing a lot of unjust things going on. I never intended it to be used by Opposition. I think they liked it, probably we were seeing things the same way," said Mr. Mayinja.

In 2011, the trend soared. Some artistes were hired by NRM, FDC, DP and other politicians seeking elective positions. Mr. Museveni would add flavor to his campaigns with his Mp'enkoni rap single. When he mounted the podium to give a speech at the pre-nomination party, he agreed to recite an acapella of the song, leaving people wondering what the song means. By (Steve Jean)

Loosely translated: The stick I cut strayed into Igara where Ntambiko reigns. Ntambiko gave me a knife which I gave to millet harvesters, who gave me millet, that I gave to a hen, which gave me an egg, that I gave to children who gave me a monkey that I gave to the king, who gave me a cow that I used to marry my wife. She gave me a child I called Mugarura who raided back what belonged to me and my fathers.

Mp'enkoni was successful, on campaign rallies and social media. On Youtube, the Mp'enkoni video had by midDecember collected some 210,000 hits online, a remarkable figure by Ugandan standards. The rapping President attempted another single release in 2015 only to hit a snag. The song, Yengoma, was hurriedly done. As a seasoned music producer noted on NTV Talking Arts preview of the song in August 2015, the Yengoma producer was not creative at all by taking the President to the studio to sing to a pre-programmed sound track. "The President is not a musician but he can do good poetry. It is easy to synchronize his poetry with a sound track.

Mr. Joe Tabula noted. Realizing Yengoma had poor reception, strategists changed to another plan. Again Bebe Cool was called in to head the Tubonga Naawe project for NRM. The Tubonga Naawe is a song recorded by a number of top musicians praising Mr. Museveni and NRM. Some of the artistes of the Tubonga Naawe promotion song move with the NRM presidential candidate, Mr. Museveni, on his campaign trail. Songs in support of Opposition are hard-hitting. Besigye Songa Mbele by Adams and Akalulu ka Colonel by Kadongokamu singer Fred Ssebaale are standing out. "I sing what I believe in," Mr. Ssebaale said, "FDC has not paid me but my song being a part of a struggle for a cause makes me proud." Mr. Ssebaale has sang for Opposition politicians like Erias Lukwago in past elections. 
The trend to work for politicians' looks like a benefitting spree for some of the artistes but where it leaves the industry is a big question. Andrew Benon Kibuuka, the head of the federation of performing artistes, says the trend is a healthy one for artistes. He is convinced artistes will earn respect first and then money.

In these recent years, artistes have not stopped at singing or acting. Many have gone ahead to seek elective positions. Some have political bias that is evident in their music or other artistic works, for example, Kato Lubwama of the Diamonds Production, who is seeking a Parliament seat for Lubaga South in Kampala; others simply want to exchange their popularity for political positions. This was egoed by Bobi Wine's critigues on his song called; situki When the going gets tough, the tough must get going,

The evolution of music as seen in the past series of Songs of Resistance is progressive. Artistes will move with what the times dictate and not their conscience. Whether they sing for politicians to earn a living or because they want to demonstrate a particular cause, that is different. What is clear is that the trend is only starting to grow. The influence of Political Mobilization Music on the status and levels of national cohesion in Nigeria had its own roots: the case study of "music performance for political mobilization and violence during 2011 general elections in Nigeria". Politics and electioneering is one of the major issues on conflict especially in Nigeria. Election campaigns go with songs, which some time results, into violence. Music is also a powerful force for political mobilization that can also result into violence due to the textual ability of the songs. This study examines the place of music in mobilizing citizens for electioneering and the result of some songs that have resulted into conflicts. It consists of analyses of the content and context of selected songs. The scope of this paper covers some of the songs for presidential aspirants of Goodluck Jonathan of Peoples Democratic Party, Nuhu Ribadu of Action Congress of Nigeria, and Muhamadu Buhari of Congress for Positive Change. This paper also focused on Abiola Ajimobi, Christopher Alao Akala, and Rashidi Ladoja gubernatorial candidates in Oyo State. It will also evaluate one Hausa song that causes violence in northern part of Nigeria. This study is pinned on entertainment- education theory. Findings revealed that music performances during the 2011 general election in Nigeria really helped in mobilizing the citizens, it also causes conflicts and violence in some part of Nigeria because of insulting texts in the songs. The paper recommends that INEC should scrutinize some political jingles and songs before they are aired. In addition, politicians should know that the songs can cause harm and violence and should avoid such. Likewise, musicians should compose political songs that will not engender conflict in the society.

African music is a powerful medium of communication, through which human actions and reactions are expressed. It provides a forum to mirror the society so that members could understand things better and learn more about life. African music focuses on the teaching of morality, building restraints in to the psyche of the public and in settling conflicts. African music has indeed played big role in objectifying, unifying and bringing peaceful co-existence among African communities. Kidula, (2008) opines that the knowledge of the African cultural value systems provides the understanding to interpret African songs and deduce full meanings from the communication experience. Music has always been the most visible attempt employed by ourselves to listen to ourselves. Music is a social organizer. It supervises the operation of established government, assists in the maintenance of the land, safeguards and perpetuates tradition. Furthermore, traditional music discourages the degeneration of personal or corporate morals, promotes social equity and fights injustice, crowns rulers, welcomes births, buries the dead, enforces rule of law and enlivens different purposes of communal get together. The year 2011 will go down in Nigeria as a year of received struggle for democracy. Kirkpatrick (1993) writes, "Democracy is a form of government in which the supreme power is vested in the people collectively, and administered by them or by officers appointed by them." No doubt when this set of leaders take over, the entire population of Nigeria was happy to participate in the election to usher in new leaders who would protect their interest and give the succour.

The effort to democratize involves matters of constitutional choice which transcends multi-party elections or replacement of one group by another in government (Olutoye, \& Olapade, (1998). In line with this statement, it becomes imperative to evolve governmental regime that will provide opportunity for all and sundry to contribute in the governing processes that will not destabilize the integrity and effectiveness of the political ideology in Nigeria. It is at this junction that the use of music comes to mind, to mass mobilize the populace into participating in the elections. Music has been tested and wholesomely discovered by people to have the power to educate the people on current burning issues on national policies. In Nigeria for instance, One of the chieftains of PDP also sang during one of the campaign rally that it is a must for PDP to win in Southwestern part of Nigeria. According to Barnes (1982), Aristotle a Greek philosopher maintains, "Music is the food for soul and has the power to move people in terms of entertainment and communication". We must therefore acknowledge countless other affirmations of music's healing and peacemaking capabilities. If music powers to heal, it also has power to harm. 
In America, the status and level of political mobilization songs in America had its roots. The song We Shall Overcome is a protest song that became a key anthem of the African-American Civil Rights Movement. It is widely speculated that African-American composer Charles Albert Tindley (1851-1933) derives the title and structure of the song from an early gospel song, "I'll Overcome Someday". However, although there are lyrical similarities, the melodic, harmonic, rhythmic and lyrical structures of Tindley's hymn are radically different from that of "We Shall Overcome". We Shall Overcome" began as a folk song, a work song. Slaves in the fields would sing, 'I'll be all right someday.' It is not a marching song. It is not necessarily defiant. It is a promise: "We shall overcome someday. Deep in my heart, I do believe." It has been a civil rights song for 50 years now, heard not just in the U.S. but also in North Korea, in Beirut, in Tiananmen Square, in South Africa's Soweto Township. The first political use came in 1945 in Charleston, S.C. There was a strike against the American Tobacco Co. The workers wanted a raise; they were making 45 cents an hour. They marched and sang together on the picket line, "We will overcome, and we will win our rights someday."

Music plays an important part in shaping identity and forming community that can result in shared meaning between people. Identity can be understood as an individual's psychological relationship to particular social category systems and memberships, together with a set of personal meanings and experiences related to those systems/memberships, such as gender, religion, class, nationality, race, ethnicity and age (Deaux, 2003). Communities are defined by a set of common characteristics, and the specific character of its commonalties defines the identity of a particular community. For example, communities are defined by specific common traits of political identity, commitment, memory, history, tradition, and culture; by variations in their degree of openness; and in their size and scope.

Music is one of the most important of these increasingly pervasive new sources of political content. It is perhaps because of the explosive rise of music as a venue of political expression that it has become so timely to take a retrospective and generalized look at the phenomenon. If politics is the blood that feeds our societies with the energy to evolve, then music is an essential ingredient to political transformation. We listen to music not only to be entertained. We listen to music to understand ourselves both individually and collectively. Yet it is precisely because music is so entertaining that it carries such great potency as a venue for political expression. It conveys more than the written or spoken word. Through rhythm and tone, music becomes a powerful link between the emotionally rich ideas of a political thinker and the listeners. We are both political and musical creatures. This is, indeed, one of the things that make it so fun to be human and this is also why it is so crucial to understand the potential of music as a mediating factor in the political transformation of society (Brown, 2008).

Mattern explains, as a sign of community, music reveals constituent elements such as beliefs, assumptions, and commitments that define the character and shape of the community. This can be seen in a wide range of examples, from the slaves who brought their music to the Americas to the use of national anthems to unify people in a nation, music used in church to express faith, or specific genres of music such as punk or country. Specific instances of music's role in community can be seen in the powerful use of music against apartheid in South Africa, the 'singing revolution' by (Tracy Chapman)

While in the Balkans where 300,000 singers gathered to sing and demand independence, and the prominent place of music in the Civil Rights and anti-Vietnam War movements in the United States for instance; Mississippi Goddamn by (Nina Simone). Music helps shape individual identity within a society, and helps to form group identity based on culture, values, religious beliefs, or class (Mattern, 1998).

Music not only accesses emotional responses and creates opportunity for mediation between people and groups; it provides healthy opportunities of engagement. Jose Junior, one of the members of the Afro-Reggae Cultural Group, explains; "Our major objective is that the youths of the favelas do not take the narco-traffickers as their idols any longer. Instead of guns, we offered musical instruments. Our power is not that of death, but that of life" (Ramos \& Ochoa, 2009). Through the activities of this group, stereotypes have been altered and new images are being created in their place through the use of these 'patriotic songs,' showing that it is possible to combat violence through creative and peaceful means (Ramos \& Ochoa, 2009). There was a need for a more systematic investigation of the ways that music could influence groups of people during electioneering period. In Kenya some political music has bee used to bring about cohesion among communities. Such include; Najitolea daima Kenya,- Eric Wainaina

According to Nketia (2004), Research on music had tended to focus on commercial, social engagement and works environments. The way that music might affect behavior during political competition has been neglected. In view of this, the following entities entrusted with regulating music and enhancing national cohesion, as a matter of urgency alleviate conflict causing compositions are explored in the next sub- sections. National Cohesion and Integration Commission (NCIC), charged Permanent Presidential Music Commission (PPMC), Music Society of Kenya (MCSK) Kenya Music Festivals (KMF). 


\section{Theoretical framework}

The studies theoretical framework was grounded in the Musical Meaning Theory. With regard to musical meaning especially in African societies, Cook et all (2001) asserts that a person is said to understand a piece of music when he is able to relate or respond to it in certain culturally defined ways. Meaning is therefore, related to the musical Experience itself (which consists of both what is derived from the music itself and what is occasioned by it in musical situation). This meaning may be communicated in several ways: through the internal properties of music, expressive changes in them which may be mirrored in the observable behavior, through creative expressions of verbal texts, the nexus between music and dance movement and between music and the context of use. It is notable that Kenya is a culturally heterogeneous Nation. Based on Nketia's theory, it is not clear to what extent the cultural prejudices influence how people respond to specific music, especially in political situations. It is possible that people derive meaning differently given their divergent appreciation of the internal properties of the music as well as situations in which it has been presented. More so, is the fact that observable behavior from the musicians may contribute to the proper communication or diversion of the intended message in the music. This theory will thus form an integral frame of reference is seeking to appreciate how people derive meaning from music. The two theories do not directly address the issues in a peace and conflict studies hence the need for the third theory just peace theory.

\section{Research methodology}

This paper adopted a mixed methods approach, using qualitative and quantitative research methodology. The target respondents (music composers, teachers, electorates and official from NIC, KMF, PPMC and groups from 4 slums working towards peace initiatives were sampled. Data was analysed by descriptive and inferential statistics using Statistical Package for Social Science (SPSS v23).

\section{Study area}

The study was conducted in Nairobi County, Kenya because since the urbanization of Nairobi which dates back to the colonial times, Nairobi has a unique and natural cosmopolitan nature. All the various Kenyan ethnic communities are present because Nairobi is still the hub of commerce. Many Kenyans come to eke a living because of its development which has incessantly attracted the rural to urban migration. Policies to reverse this trend have not yielded much fruit. Nairobi is microcosm of Kenya as a nation, Africa and the rest of the world (world embassies and international organizations have their headquarters in Nairobi.) This study involved how humanity reacted to political mobilization music influencing national cohesion in Kenya.

\section{Figure1.Map of Nairobi County Kenya.}

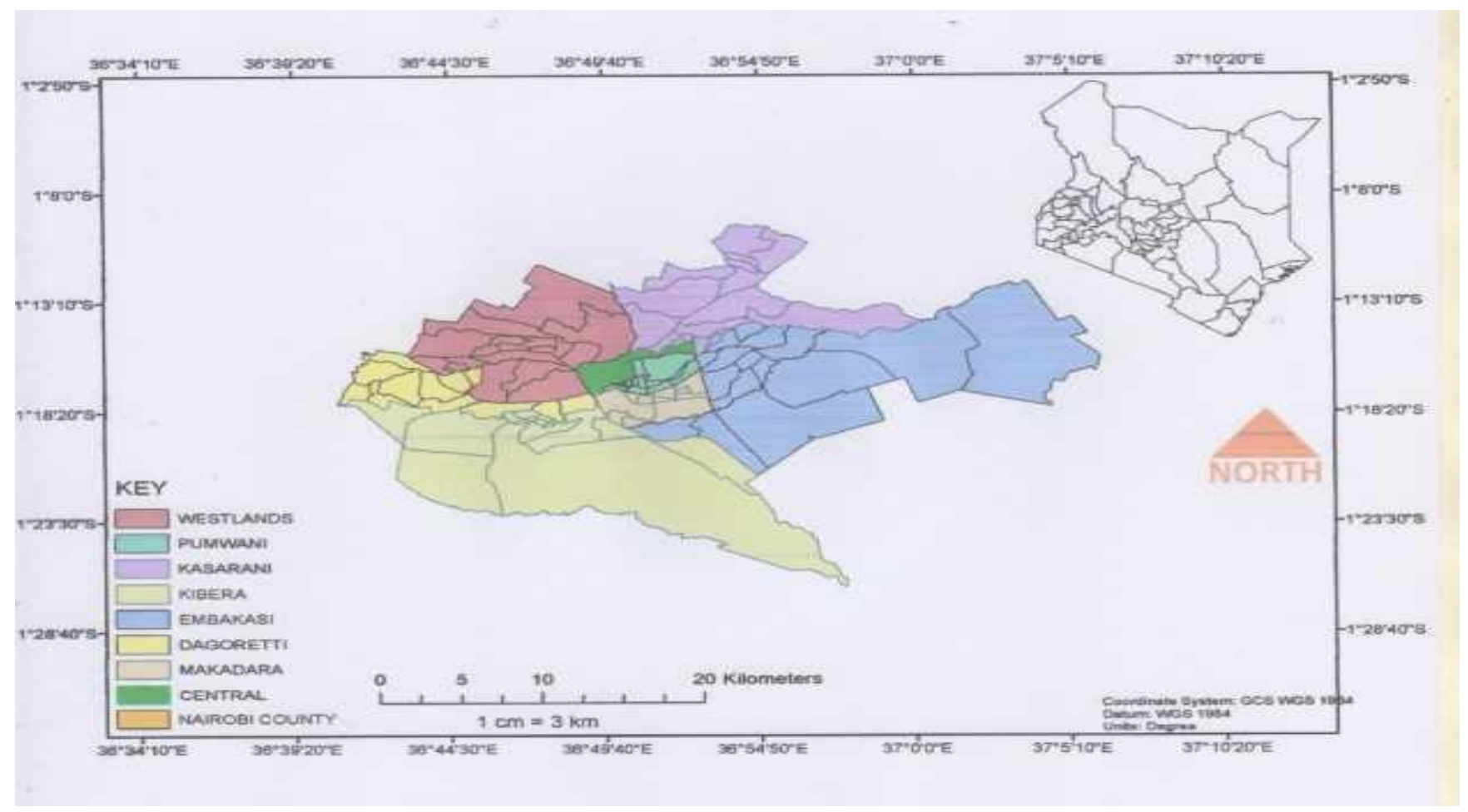




\section{Results and Discussion}

The study sought to find out the influence of political mobilization music on the status of national cohesion in Nairobi county Kenya under various variables. The findings are discussed in the subsequent sub headings. Data collected was gleaned, coded and analysed through Excel and SPSS and the results were as follows:-

\subsection{Influence of PMM on the status of National Cohesion in Nairobi County, Kenya.}

The study sought to investigate the influence of Political Mobilization Music on status of national cohesion in Nairobi County. Nairobi was the most cosmopolitan City in the entire nation with a general population of 3,138,369 (KNBS, 2009). Nairobi has been bedrock of political mobilization music during every general elections period in Kenya. Political mobilization music has also been known to course conflicts or bring about peaceful co-existence during such times depending on how it is composed either on a positive or negative way.

According to Brown (2008), United States gained their independence July 4, 1776. After independence in 1788 the George Washington's supporters composed, "God Save George Washington". his supporters wrote songs such as "God Save George Washington" - a thinly veiled adaptation of "God Save the King" - and "Follow Washington," which recalled his military leadership and the experience of all veterans of the Revolutionary War. John Adams and Thomas Jefferson would follow suit and adopt their own campaign songs during the election of 1796, thus establishing a now unshakable precedent. This was the praise song composed to praise Washington (Grand 2003). Indeed it did had no impact on national cohesion of the country but was very divisive instead. The responses from participants were analyzed and interpreted using frequencies and percentages. The findings are presented in the table 1

\section{Table 1.Percentage distribution of influence of PMM on the status of national cohesion in Nairobi County}

\begin{tabular}{llll}
\hline $\begin{array}{l}\text { Status of National } \\
\text { Cohesion in Nairobi }\end{array}$ & Response & Frequency & Percentage (\%) \\
\hline Peaceful coexistence & Yes & 84 & 54.0 \\
& No & 72 & 46.0 \\
Trust among communities & Yes & 47 & 30.0 \\
& No & 109 & 70.0 \\
\multirow{2}{*}{ Tolerance among each other } & Yes & 101 & 65.0 \\
& No & 70 & 45.0 \\
Diversity and inclusivity & Yes & 97 & 62.0 \\
& No & 59 & 38.0 \\
\hline
\end{tabular}

Source: Author 2019

As the findings indicated, that the influence of political mobilization music on the status of National cohesion was as follows; on peaceful coexistence 45\% ( $n=156)$ said yes while $46 \%(n=156)$ said no. these findings were backed by a key informant from Kenya Music Festival who said,

To some extent, it can be said that residents of Nairobi live peacefully with one another. This is seen even more when there are calamities etc., there are rarely cases of inter-ethnic fights in Nairobi. Does this mean then that we are cohesive? She queried (Key informant KMF official 2019)

Again, 65\% ( $\mathrm{n}=156)$ respondents said yes on tolerance among each other while $45 \%(\mathrm{n}=156)$ said no. On diversity and inclusivity, 62\% $(\mathrm{n}=156)$ said yes while $38 \%(\mathrm{n}=156)$ said no. Trust among communities had a negative response of $70 \%(\mathrm{n}=156)$ since it is hard for people to forget where they come from due to ethnicity. These findings are in line with the reviewed literature that indicated that political mobilization music could be rated in equal measure as a cause of conflict or promotion of peaceful co-existence (O'Connell \& Morgan 2010). Music idolizes political personalities, those songs against specific political leader causes unrest, abuse of political songs causes' conflict. An FGD 1 member who quipped echoed this; The songs are good but people's minds are corrupted by politicians e.g. "mnataka nani" "uhuru ni withu"hague bond" Ngatha wa gichugu" praise Martha Karua to president it causes division that had negative impact on the women agenda. (FGD 1, Kawangware peace initiative, 2019)

Patriotic songs on the other hand stimulates activism in people, patriotic songs call for cohesion and creates empathy, political songs craft praises for political candidate, both political and patriotic songs shape political decision, political songs has the power to communicate hidden political directions. These sentiments were in agreement with those of a member from Mathare Slum Peace ambassador who said: Political mobilization music through roadside shows, dialogues, theater/school performances, forums, activities reduced tension hence building national cohesion and peace in Kenya (FGD 3, Mathare Peace ambassador, 2019) 
These findings are in line with those of Alusekunye \& Obanyi (2012) studies undertaken in Nigeria on Musical Forms in Songs for Political Mobilization during 2011 General Elections in Nigeria. Findings revealed that music performances during the 2011 general election in Nigeria have different musical forms and really helped in mobilizing the citizens.

\subsection{PMM enhances the status of togetherness towards national cohesion.}

Musicians created songs reminding Kenyans of the independence struggle and the sacrifices that had resulted in selfrule. This was more under the rule of the first President Jomo Kenyatta. The song "Wimbo huu ni wimbo wa historia" The song goes by the lines, "Wimbo huu ni wimbo wa historia watu mnaombwa sikize kwa makini, Ilikuwa Octoba 1952 watu wote tulisikia Kenyatta ameshikwa." was particularly known for its emotive tone in expressing the tales of the Kapenguria 6, particularly Mzee Jomo Kenyatta.It was written in the 1970's Enock Ondego and was first sang by primary school pupils to President Jomo Kenyatta on his tour of Taita Taveta (Kariuki 2002). This indeed enhanced the status of togetherness towards national cohesion in Kenya. Patriotic songs were composed to show how Kenyans owned the country after struggle to chase colonial rule.

The researcher sought to investigate the performance of patriotic songs enhances a sense of belonging and togetherness. Table 2 presents the findings,

\section{Table 1. Percentage distribution on whether PMM enhances the status togetherness.}

\begin{tabular}{lll}
\hline Responses & No of respondents & No in Percentage \\
\hline Strongly Disagree & 0 & 0.0 \\
Disagree & 0 & 0.0 \\
Neutral & 3 & 2.0 \\
Agree & 33 & 21.0 \\
Strongly Agree & 120 & 77.0 \\
Total & 156 & 100 \\
\hline
\end{tabular}

Source: Author 2019

The results from table 2 shows that $77 \%(\mathrm{n}=156)$ of the respondents strongly agree that performance of patriotic songs enhances a sense of belonging and togetherness, $21 \%(n=156)$ of the respondents' agree to the notion while $2 \%$ $(n=156)$ of the respondents were neutral to the notion. This implies that performance of patriotic songs enhances a sense of belonging and togetherness supported by $77 \%(\mathrm{n}=156)$ of the respondents.

These findings were echoed in a separated study undertaken by Njuru (2012) when researching on the role of music in peace building and reconciliation after 2007/2008 post -election violence in Kenya. Respondents were asked on whether music played a role in conflict prevention. Music was found by majority being $83 \%(\mathrm{n}=156)$ to contributing positively in conflict prevention by assessing other elections while only $17 \%(\mathrm{n}=156)$ objected to it.

It was stated by respondents that music creates awareness on conflict emerging issues and provides alternative solutions among the parties. It also brings solidarity, giving participants a feeling of belonging and a sense of community as Kenyans regardless of tribe, gender, age or social status.

Some respondents gave additional comments. Some stated that music alone cannot play a role in peacebuilding and reconciliation, but it is catalyst to the processes of peacebuilding. Depending to communities, the kind of conflict and extend to which the harm has been caused, it's important that artist work closely with people from conflicting communities to come up with music or songs that helps in addressing their needs and conflict in a holistic manner. Other respondents in the same study argued that more support should be given to local artist who promote peace songs in local language to produce more songs, be invited to many local functions to entertain the occasion. Also, music and other creative subjects should be brought back to Kenyan school curriculum/syllabus.

\subsection{PMM possesses a strong sentimental value that enhances the status of national cohesion.}

Kariuki (2002) quoted Prof Akama encouraging students and political mobilization music composers to compose patriotic songs to enhance national cohesion and integration among the country's ethnic communities in Kenya. He said that besides using the songs to preach peace and harmony, patriotic songs composed by students will inculcate a culture of patriotism among school children thus ensuring students grow up loving their country and serving it with dedication. Akama underscored the importance of young people composing patriotic songs.

I agree with Akama's sentiments. Indeed the songs should not only be in praise of the country, but also in memory of the country's founding fathers and other heroes who fought for the country's independence from the colonial administrations. Patriotic songs are not only for mere entertainment, but as a symbol of a country's unity and historical memory on the country's struggle and attainment of independence and self-rule from the colonial masters. 
Patriotic songs composed by students themselves will motivate them to love and defend their country in their various spheres of life. Similarly, such songs will be kept in a bid to enable the future generations learn their country's history. The researcher sought to find out if patriotic songs possess a strong sentimental value that enhance and direct people's strength towards defending our Country's heritage. The results are as shown in figure 2

Figure 2. Percentage distribution on whether PMM possess a strong sentimental value that enhances the status of national cohesion.

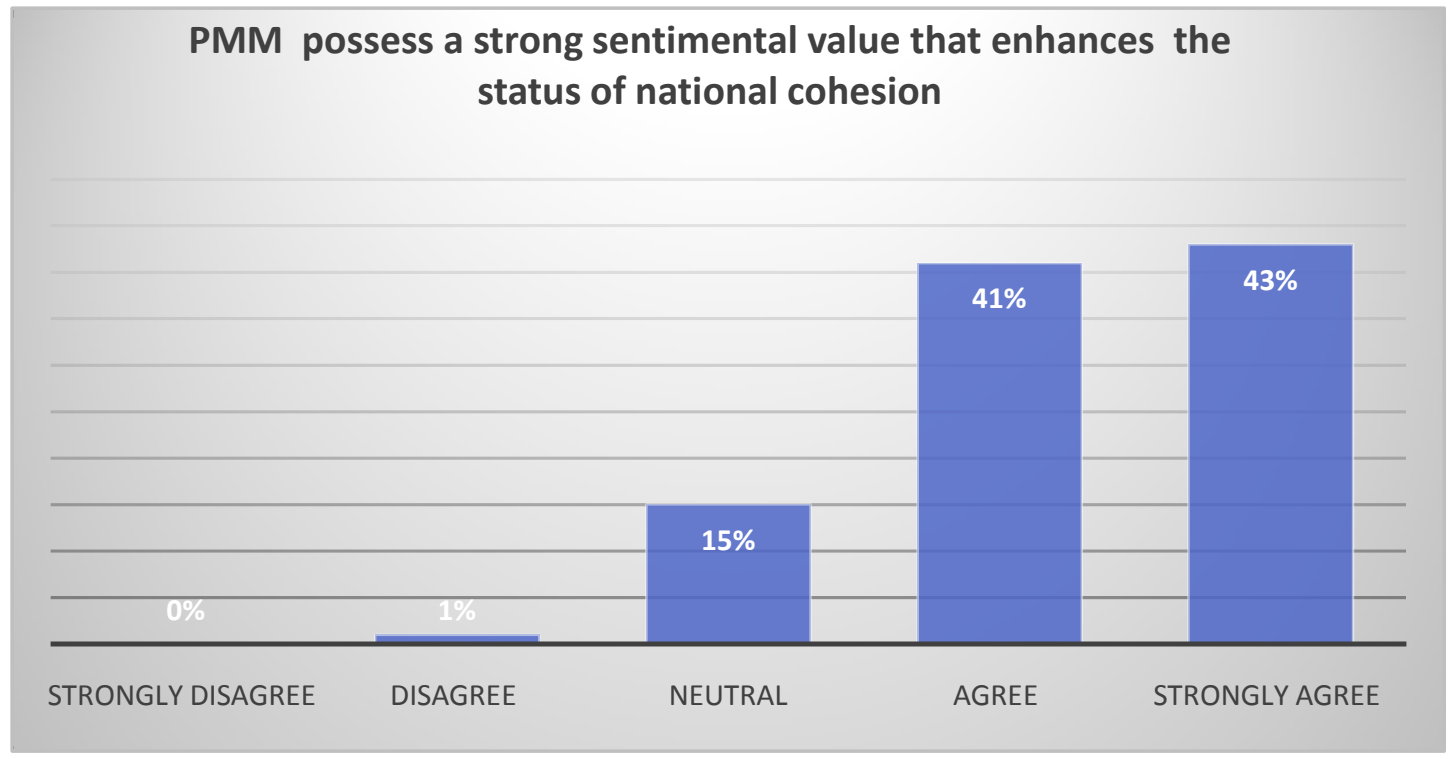

The study findings from figure 4.18 above depicts that the respondents who listen to patriotic songs possess a strong sentimental value that enhances defending our countries' heritage, this is supported by $41 \%(n=156)$ and $43 \%(n=156)$ of the respondents who responded in favor of the statement. This is because most of these patriotic songs carry with it a sense of value attached to our county's heritage. $15 \%(n=156)$ of the respondents were neutral to the statement because some of them have no sense of heritage with respect to movement from one location to another, while $1 \%(\mathrm{n}=156)$ of the respondents disagreed with the notion.

Averagely $84 \%(n=156)$ of respondents agreed to the fact that Patriotic songs possess a strong sentimental value that enhance and direct people's strength towards defending the Country's heritage.

A key informant concurred with these findings by sharing; Before Independence, Kenya was colonized by the British. After the independence in 1963, Kenya became a Sovereign State with one president under one Party rule. Music that was composed then was in praise of Kenya our Country for example Kenya nchi yangu (Kenya my country) this was more under the rule of the first President Jomo Kenyatta (Key informant KMF officer 2019)

A study undertaken in Kenya by (Njuru 2012) in the same vain indicated that Mungu Baba- song by Rufftone and The GSU Choir came handy in preaching against political vices and promoted national cohesion. After the 2007/2008, postelection violence, gospel artist Rufftone, real name Roy Smith Mwatia, was inspired to write a song preaching peace, love and unity ahead of the March 2013 elections in conjunction with the GSU choir and National Youth Orchestra of Kenya. This song has become an acclaimed national song for unity and peace today.

Another significant song is Tushangilie Kenya- a song by Mwalimu Thomas Wasonga, now the Director of PPMC and a Brand Kenya Ambassador for upholding national values. It is a famous song that reiterates the love for Kenya by its people. It also features in the PPMC's production of "May We Dwell in Unity". Other songs that have become recognized with the call for peace and love for Kenya in both past and present times include Wakenya Pamoja for Peace- Various Artists, Harambee Harambee- Daudi Kabaka, Najivunia Kuwa Mkenya- Trapee and Avril, Coming Home- Nameless, Kenya Nchi Yangu- Kakai Kilonzo, My Land Is Kenya- Roger Whittaker (also covered by the Moipei Quartet), Voter vs. Vulture- Juliani, Never Again- Dela, If You Believe- Camp Mulla, Change- Various Artists, Marungu- Jimmy Gait, Mama Kenya- Juliani ft Various Artists ( translates PEV stories into the song especially from Dagorretti.

These findings are in agreement with Deni's 2015 sentiments; “These forays into political philosophy, colonial history and enlightenment thought also help us to understand the peculiar relationship that developed between the Communist Party of the United States of America (CPUSA) and folk music, a relationship that shaped the production and reception of protest music in the United States from the Great Depression to the present. 
Like the IWW, the CPUSA viewed music as having great mobilizing and unifying potential but unlike the IWW they did not draw on and modify popular tunes; instead, they turned to "folk" music, music that was created by and for a people. "Folk" material, however, was understood as coming from a rural people inhabiting a pre-modern age. Consigned as such to the historical past it was not a given that such material would appeal to a movement that was fundamentally shaped by a progressive and teleological view of history. According to Denisoff, the success of the Bolshevik revolution in 1917 gave credibility to the idea that a people's art could be mobilized to agitate people in favor of a revolution, and that a movement could push an industrially undeveloped country to pass over the capitalist stage to socialism - in this paradigm art was a tool to fast-forward the inexorable march of history (Emeka, 2018). These findings support the fact that Patriotic songs possess a strong sentimental value that enhance and direct people's strength towards defending a Country's heritage.

\section{Conclusion}

This paper focused on assessement of the influence of political mobilization musicic status of National cohesion in Nairobi County,Kenya. From the findings, it was concluded averagely $75 \%(n=156)$ of all respondents agreed to the facts that; PMM on the Status of National Cohesion in Nairobi County has brought Peaceful coexistence, Tolerance among each other, Diversity and inclusivity and that trust among communities is still lower because ethnicity is still considered among the people. On whether PMM brought about peaceful coexistence among Kenyans, 54\% ( $\mathrm{n}=156)$ said yes while $46 \% \quad(\mathrm{n}=156)$ said no, 30\% $(\mathrm{n}=156)$ agreed to the fact that PMM brought about trust among communities while 70\% $(\mathrm{n}=156)$ disputed. On whether PMM influenced tolerance among each Kenyans, $65 \%(\mathrm{n}=156)$ said yes $45 \%(\mathrm{n}=156)$ said no. 62\% $(\mathrm{n}=156)$ of respondents said PMM brought about diversity and inclusivity among communities while 38\% ( $\mathrm{n}=156)$ disputed.

At neutral position, patriotic songs possess a strong sentimental value that enhance and direct people's strength towards defending the Country's heritage. Finally, both political and patriotic songs have been used over the years to create identity amongst Kenyans.

\section{References}

Barnes, J. (1982). Creativity and composition in music. Aristotle. New York: Oxford University Press

Brown, C. (2008). Politics in Music and Political Transformation from Beethoven to Hip-

Cook ,N (2001).Understanding music and Performance

Deaux, K. (2003). Reconstructing Social Identity. Personality and Social Psychology Bulletin: 19(1).

Denisoff (2015),Protest and Music-Oxford Research encyclopedia ofPolitics

Emeka, L.N. (2018), Radio Root-Broadcasting and Rural Development in

Grant M. J. (2003). Music and Genocide: The Trial of Simon Bikindi at the Hop: Farsight Press First published by Farsight Press, a member of Farsight, Inc.International

Kariuki, J. (2002, November $3^{\text {rd }}$ ). Flashback to Praise songs Era. 'Sunday Nation.

Kenya National Bureau of Statistics (2009): Nairobi Government Printers.

Kidula, J (2008).The Rise of Religious Music Industry

Kirkpatrick, J (1993).The Global Crisis of democracy-WSJ

Lopéz-Vinader, M. (2008). Music therapy: Healing, growth, creating a culture of peace. New

Mattern, F. (1988). Virtual Time and Global States of Distributed Systems, in Cosnard, M.,

NaomiZic. Psychology of Music. August 2015; https://journals.sagepub.com.

Ndunde (2016). From Cyberspace to the Public: Rumor, Gossip and Hearsay in the Nigeria Paper Presented at a Conference on Communication and Development. Organized by News Agency of Nigeria.

Njuru, A,W (2012)The role of music in Peacebuilding andreconciliation

Nketia, J. H. K. (2004). The Creative Potential of African Art Music in Ghana: A November 2017.

O'Connell J.M. and Salwa El-ShawanCastelo-Branco (2010). Music and Conflict:Olutoye, O and Olapade, J. A. (1998), Implements and Tactics of War among the Yoruba. War and Peace in Yorubaland. Akinjogbin, A Ed. Ibadan: H.E.B. PP 1793-1893.

Paradoxes of the 2007 General Election in Kenya. 12 ${ }^{\text {th }}$ General Assembly Governing the African Public Sphere.Proc. Workshop on Parallel and Distributed Algorithms, Chateau de Bonas, France: Elsevier, pp. 215-226.

Ramos, S., \& Ochoa, A. (2009). Music and human rights: The AfroReggae Cultural Group and the youth from the favelas as responses to violence in Brazil. Champaign, IL: University of Illinois Press.

Reeves-Smith, T. L. (2007). Entertainers who lead: A phenomenological study of leadership and celebrity politics (doctoral dissertation, Gonzaga University, 2007). Digital Dissertations.

Rhodes (1962:18) Topical and Political music-open edition York: I.B. Tauris \& Co Ltd. 